\title{
EL CONCEPTO DE DELITO EN EL SISTEMA PENAL RUMANO
}

\author{
Valentina I. Dipse ${ }^{1}$
}

Resumen: El vigente Código penal rumano, aprobado por la Ley 286/2009, de 17 de julio y en vigor desde el 1 de febrero de 2014, ha optado por incluir una definición legal de delito en el art. 15 del Capítulo I del Título II. Se trata de uno de los elementos más originales y difíciles de interpretar del Código penal rumano que mantiene dividida a la doctrina penal rumana tanto en lo que se refiere a las categorías que lo integran como al alcance o ubicación de estas. En el presente trabajo se destacan los problemas interpretativos que aún siguen planteando ciertas categorías doctrinales que integran el concepto de delito del art. 15 del CPRO, como son vinovăția o imputabilitatea y se proponen soluciones interpretativas -respetuosas con la letra de la Ley- tendentes a armonizar el sistema penal rumano con las construcciones teóricas de los otros Estados Miembros de la UE.

Palabras clave: Concepto de delito, Tipicitate, Vinovăție, Antijuridicidad, Imputabilitate.

\section{Recibido: marzo 2020. Aceptado: julio 2020}

1 Doctora en Derecho. ORCID 0000-0002-5411-5036. Departamento de Derecho Público. Universidad de Cantabria. Avda. de los Castros s/n. 39005 Santander. E-mail: dipsevi@unican.es 


\begin{abstract}
The current Romanian Criminal Code, approved by Law 286/2009, of July 17 and in force since February 1, 2014, has chosen to include a legal definition of crime in art. 15 of Chapter I of Title II. It is one of the most original and difficult to interpret elements of the Romanian Criminal Code that keeps Romanian criminal doctrine divided both in terms of the categories that comprise it and the scope or location of these. This paper highlights the interpretative problems that still arise from certain doctrinal categories that integrate the concept of crime of art. 15 of the CPRO, such as vinovăția or imputabilitatea and interpretive solutions are proposed -respectful of the letter of the Law- aimed at harmonizing the Romanian penal system with the theoretical constructions of the other EU Member States.
\end{abstract}

Keywords: Concept of crime, Tipicitate, Vinovăție, Unlawfulness, Imputabilitate.

\title{
1. Breve evolución histórica del Derecho penal rumano
}

El éxito de la investigación comparatista depende, no sólo del manejo por parte del investigador de los idiomas propios de los ordenamientos objeto de estudio ${ }^{2}$, sino, también, de la comprensión del "espíritu" de tales ordenamientos. De modo que, a efectos de lograr esa comprensión, en el caso que nos ocupa, se considera preciso el recurso a los elementos históricos que han marcado la evolución del Derecho penal rumano y, por ende, de la Ciencia del Derecho penal.

2 No sólo a efectos de utilizar las fuentes bibliográficas originales, sino también porque, tal como manifiesta DE LA SIERRA, "el estudioso del Derecho ha de ejercer, además, las veces de traductor que importa términos extranjeros y los ha de adaptar al contexto de la lengua en que escribe”. DE LA SIERRA, S, Una metodología para el Derecho Comparado europeo, Ed. Thomson Civitas, Madrid, 2004, pág. 104. 
El punto de partida de este estudio relativo a la evolución del Derecho penal rumano, lo constituye el Código penal de $1864^{3}$-inspirado en el Código penal francés de $1810^{4}$ con el que se inicia la época del Derecho penal moderno y de la Ciencia del Derecho penal ${ }^{5}$ en Rumanía ${ }^{6}$.

La Ciencia del Derecho penal rumana conoció un intenso y profundo desarrollo en la primera mitad del siglo $\mathrm{XX}$. El primer gran trabajo en materia penal, estructurado en tres volúmenes, fue publicado en el año 1912 por el Prof. TANOVICEANU. El Tratado de derecho y de procedimiento penal de TANOVICEANU "exponía de manera sistemática los principios del Derecho penal, las diferentes escuelas y corrientes doctrinales existentes en materia penal con expresas referencias de derecho comparado y un profundo análisis del derecho penal rumano vigente en esa época"7. Ahora bien, el verdadero auge de la dogmática penal rumana se produjo en el período interbélico con las grandes obras de VINTILĂ DONGOROZ, TRAIAN POP y NICOLAE BUZEA. Destaca, por sus grandes aportaciones y concepciones adelantadas a su época, el Profesor DONGOROZ cuyo Tratado de Derecho Penal ${ }^{8}$ es considerado por la Doctrina "verdadero monumento del pensamiento jurídico rumano" .

3 Edificado sobre los principios propios de la Ilustración -el principio de legalidad, el de humanidad de las penas, el de igualdad ante la ley, etc.el Código penal de 1864 estuvo en vigor hasta el 1 de enero de 1937.

4 RICEANU, J., "Analiza trăsăturilor esenţiale ale infracţiunii în legea penală română”, en Revista de Drept Penal, Núm. 1, Anul XVII, ianuarie-martie, 2010, Bucarest, pág. 15.

5 Según MITRACHE, C./MITRACHE, C., Drept Penal român. Partea generală, Ed. Universul Juridic, $3^{\mathrm{a}}$ ed., Bucarest, 2016, pág. 34, la Ciencia del Derecho penal explica y fundamenta la necesidad y los cometidos del Derecho Penal, así como los métodos y modos de prevención y represión del fenómeno delictual.

6 BULAI, C., Manual de Drept Penal. Partea Generală, Ed. All Educational, Timișoara, 1997, pág.43.

7 BULAI, C., Manual de Drept Penal. Partea Generală, cit., pág.44.

8 Publicado en el año 1937 y reeditado en el año 2000 por la Asociación Rumana de Ciencias Penales. 
El desarrollo doctrinal en Rumanía, sin embargo, pronto se vio frenado por la instauración, en el año 1938, del régimen dictatorial de Carol II, que puso punto final a la democracia parlamentaria y abrió un largo periodo ${ }^{10} \mathrm{de}$ represión del pensamiento científico penal y supresión de la libertad de expresión que, necesariamente, repercutió en el desarrollo normal de la Ciencia penal rumana. Posteriormente, finalizada la Segunda Guerra Mundial, en el año 1947, se instauró un régimen político comunista que, siguiendo el modelo soviético, transformó el Derecho Penal en un instrumento de represión política ${ }^{11}$.

Si durante la dictadura de Carol II la Ciencia del Derecho penal se vio ralentizada, durante la época comunista padeció una auténtica persecución y "amputación", ya que, al mismo tiempo que se perseguía a los grandes especialistas en materia penal, se promovía "la formación" de juristas afines al régimen comunista a los que no se exigía preparación jurídica alguna ${ }^{12}$. Además, la ideología marxista sobre la que se edificaba el comunismo influyó, no sólo en la producción científico-penal, sino, también, en la legislación positiva. Así, en el año 1968 se aprobó un nuevo Código penal, de inspiración soviética ${ }^{13}$, que prescindía de la tradición penal rumana de la que hacía gala el Código penal de 1936 -en el que se reflejaban las concepciones propias de las escuelas clásica, positivista y neoclásica ${ }^{14}$, , que, con numerosas modificacio-

9 PASCU, I., Drept Penal. Patrea Generală, Ed. Hamargiu, $2^{\text {a }}$ ed., Bucarest, 2009, pág. 10.

10 Los regímenes totalitarios se sucedieron sin interrupción desde el año 1938 hasta la Revolución de 1989.

11 BUlAI, C., Manual de Drept Penal. Partea Generală, cit., pág. 45.

12 Según relata BULAI, se trataba de personas que carecían de toda formación, a las que "ni tan siquiera se les exigía tener estudios medios". BULAI, C., Manual de Drept. Penal Partea Generală, cit., pág. 45.

13 Con influencias del Derecho penal francés e italiano.

14 MitRACHE, C./MITRACHE, C., Drept Penal român. Partea generală, cit., pág. 46. 
nes normativas, mantuvo su vigencia hasta el 1 de febrero de 2014, cuando entró en vigor al vigente Código Penal rumano $(\mathrm{CPRO})^{15}$.

A pesar de haber trascurrido treinta y un años desde la caída del comunismo, sus huellas todavía se mantienen en ciertos ámbitos y sectores de la sociedad rumana, entre los que destaca el de la política criminal y legislación penal positiva. Por lo que respecta la doctrina penal, las reminiscencias del pasado político de Rumanía, hoy en día, siguen marcando su actual desarrollo ${ }^{16}$. Ahora bien, desde la caída del comunismo, pero, sobre todo, desde la aprobación en el año 2009 del vigente Código Penal, la Doctrina penal rumana ha realizado grandes esfuerzos por desarrollar y actualizar la Dogmática penal, destacando en este sentido los substanciales progresos verificados en el ámbito de la Teoría General del Delito.

\section{El concepto de delito en la legislación penal rumana}

Siguiendo con la tradición instaurada por el CPRO de 1969, el vigente CPRO, aprobado por la Ley 286/2009, de 17 de julio ${ }^{17}$ y en vigor desde el 1 de febrero de 2014, ha optado por incluir una definición legal de delito en el art. 15 del Capítulo I, del Título II.

15 Aprobado por Ley 286/2009, de 17 de julio de 2009 y publicado en el Monitorio Oficial, Núm. 510, de 24 de julio, de 2009.

16 El desarrollo doctrinal, en la actualidad, está fuertemente marcado y limitado por las tensiones existentes entre las tradicionales concepciones marcadas por la ideología comunista y las nuevas tendencias doctrinales de influencia ítalo-germánicas. Véase, RICEANU, J., "Analiza trăsăturilor esenţiale ale infracțiunii în legea penală română”, en Revista de Drept Penal, cit. pág. 26.

17 Publicada en el Monitorio Oficial, Núm. 510, de 24 de julio de 2009. http://www.monitoruljuridic.ro/monitorul-oficial/510/2009-07-24/, [consultado el: 04/05/2017]. 
Tal como se indica en la Exposición de Motivos del Proyecto de Código penal ${ }^{18}$, la nueva definición de delito destaca como uno de los elementos más originales del Código. Esta originalidad se debe, no tanto al hecho de que el Legislador se aventurara a fijar legislativamente el concepto material de delito - pues esto ya lo había hecho en el CPRO de 1969- cuanto al contenido material de dicha definición. Así el art. 17 del CPRO de 1969 definía el delito como "el hecho que presenta peligro social, cometido con vinovăție ${ }^{19} \mathrm{y}$ previsto por la ley penal" 20 .

\subsection{Sobre la definición de delito en el CPRO DE 1969}

La definición comprendida en el art. 17 CPRO de 1969 era una definición material, de inspiración soviética cuyos elementos integrantes eran: el peligro social ${ }^{21}$, vinovăția ${ }^{22}$ y la previsión del hecho en la ley penal. ${ }^{23} \mathrm{~A}$ pesar de su configura-

18 Disponible en: http://www.just.ro/Portals/0/Coduri/coduri_60309/ Expunere $\% 20 \mathrm{de} \% 20$ motive $\% 20$ Proiectul $\% 20$ Legii $\% 20$ privind $\% 20$ Codul $\% 20$ Penal- $\% 20$ forma $\% 20$ transmisa $\% 20$ Parlamentului.doc., [consultado el: 27/02/2017].

19 El término "vinovăție", en el lenguaje común, tiene el significado de culpabilidad en el sentido de responsabilidad, sin embargo, en el marco de la definición del concepto de delito, como se verá más adelante, su significado varía.

20 Art. 17 CP 1969 (1) "Infracţiunea este fapta care prezintă pericol social, săvârşită cu vinovăţie şi prevăzută de legea penală”.

21 El peligro social -elemento propio de las legislaciones de inspiración soviética- era el elemento que, desde un punto de vista material, diferenciaba el ilícito penal de otros ilícitos.

22 Bajo el imperio del ya derogado CPRO de 1969, la Doctrina penal rumana, de forma unánime, entendía que vinovăția, en su vertiente de categoría dogmática, reflejaba la relación subjetiva existente entre el autor y el hecho socialmente peligroso que le es atribuido como propio. En palabras de BULAI "para que un hecho sea constitutivo de delito se debe constatar la existencia de una relación de causalidad psicológica entre el sujeto y el hecho socialmente peligroso. Es decir, se debe constatar que el hecho le es imputable, no solo físicamente, sino también psíquicamente”. BULAI, C., Manual de Drept Penal Partea Generală, cit., pág. 154.

23 La Doctrina penal tradicional entendía que esta categoría, en cuanto expresión del principio de legalidad, se traducía en una reserva de ley 
ción, basada en la exigencia cumulativa de tres elementos, el concepto de delito contenido en el CPRO de 1969, nada tenía que ver con el clásico concepto tripartito de delito construido por VON LISZT ${ }^{24}$ y BELING. La teoría que se encontraba en la base del CPRO de 1969 -y que sigue marcando el desarrollo del sistema penal rumano aun en la actualidaden cuanto variante del sistema de dos elementos actus reus y mens rea, configuraba el delito en torno al contenido de la infracción ${ }^{25}$, cuyos elementos integrantes -el objeto de protección penal, los sujetos de la infracción, latura obiectiva ${ }^{26}$ o, lo que es lo mismo, la conducta típica y latura subiectivă ${ }^{27}$

en materia penal. De modo que, desde este planteamiento doctrinal, la previsión del hecho en la ley penal no es lo mismo que la tipicidad -la cual recibe el nombre de contenido de la infracción y, como a continuación se verá, desde esta perspectiva, ocupa un lugar diferente en la Teoría general del delito-. Véase en este sentido, PASCU, I., Drept Penal. Patrea Generală, cit., pág.120. Otro sector doctrinal, que se podría llamar moderno, entiende que esta categoría es, en verdad, la tipicidad, de modo que, en su seno, además de los elementos objetivos típicos, se vuelve a analizar Vinovăția, pero, esta vez, en su vertiente de elemento subjetivo: intención o culpa. Por todos, STRETEANU, F., Tratat de drept penal. Partea Generală, Vol. I., Ed. C.H. Beck, Bucarest, 2008, pág. 343 y ss.

24 Es decir, tipicidad, antijuridicidad y culpabilidad.

25 Véase, RICEANU, J. "Analiza trăsăturilor esenţiale ale infracțiunii în legea penală română”, en Revista de Drept Penal, cit., págs. 19-20.

26 Laturea obiectivă es, según DONGOROZ, V., Drept Penal (Reeditarea ediţiei din 1939), Ed. Asociaţia Romana de Stiinţe Penale, Bucarest, 2000, pág. 177, "la actividad física (actus reus) a través de la que se realiza la infracción".

27 El elemento subjetivo, es decir, mens rea, está conformado por la concurrencia de dos factores: el factor volitivo y el factor intelectivo. Según la Doctrina penal rumana, el factor volitivo es la fuerza espiritual que propulsa la energía física, lo que significa que interviene antes que la actividad física, manteniéndose invariable durante todo ese proceso. A diferencia del factor volitivo, el factor intelectivo o conciencia, conoce tres géneros: el dolo, la culpa y la preterintencionalidad. Así, según DONGOROZ, V., Drept Penal (Reeditarea ediţiei din 1939), cit., pág. 192, "la presencia del factor intelectivo marca Vinovăția del sujeto que ha realizado la actividad física, porque mientras el factor volitivo nos enseña que la energía propulsiva de la voluntad del agente se encuentra en la base de su actividad física y, por consiguiente, el hecho pertenece 
o elemento subjetivo- conforman lo que en la Doctrina española se conoce como Tipicidad. De modo que, la Doctrina penal rumana ha construido la Teoría General del Delito sobre dos pilares, que son: las características esenciales del delito -lo que para nosotros sería el concepto dogmático de delito-y el contenido de la infracción -o de la incriminación ${ }^{28}$, que es lo que para nosotros sería la Tipicidad-. La función que desempeña cada uno de estos elementos es distinta. Así, mientras que el análisis de las características esenciales del concepto de delito proporciona criterios generales que sirven para diferenciar el ilícito penal de otras formas de ilícito; el análisis del contenido de la infracción sirve para distinguir los ilícitos penales entre sí, ya que "reúne la totalidad de las condiciones legalmente exigidas para que un determinado hecho sea constitutivo de infracción" 29 .

Así planteado, se pone de manifiesto, en primer lugar, que para la Doctrina penal rumana el contenido de la infracción -la Tipicidad-era, junto a las características esenciales -el concepto dogmático de delito-, la base sobre la que se construyó la Teoría General del Delito en el sistema penal rumano. En segundo lugar, este planteamiento doctrinal explica el tratamiento paralelo que reciben ciertos conceptos -como, por ejemplo, el de vinovăție ${ }^{30}$. En tercer lugar, y como corolario de lo anterior, resulta que la previsión del hecho en la ley penal, en cuanto categoría integrante del concepto de

a ese sujeto (imputación de hecho), el factor intelectivo nos indica la actitud de la conciencia del agente, en relación con la actividad física por él realizada, actitud que nos permite ver si podemos afirmar la culpabilidad del agente (imputación psíquica o culpabilidad). El estudio del factor intelectivo es, por consiguiente, el estudio de la culpabilidad (vinovăției) y los tres géneros de factores intelectivos: dolo, culpa y preterintencionalidad nos dan los tres géneros de culpabilidad: el dolo, la culpa y la preterintencionalidad".

28 PASCU, I., Drept Penal. Patrea Generală, cit., pág.122 y ss.

29 BULAI, C., Manual de Drept Penal. Partea Generală, cit., pág. 166.

30 Cuestión que, en líneas posteriores, se retomará. 
delito, no podía significar más que una reserva de ley en materia penal, pues, según esta teoría, la Tipicidad o contenido de la infracción es un componente de la Teoría General del Delito, ubicado extramuros del concepto dogmático strictu senso. En resumen, la Teoría del delito contiene, por un lado, el concepto dogmático de delito $\mathrm{y}$, por otro, pero separado, el de la Tipicidad.

\subsection{Definición de delito en el CPRO de 2009}

La definición legal de delito prevista en el art. 15 del vigente CPRO, a la vez que renuncia al peligro social, introduce dos nuevas categorías dogmáticas: la antijuridicidad y la imputabilidad (imputabilitatea). Así, según lo dispuesto en el art. 15 (1) CPRO de 2009, "[e]l delito es el hecho previsto por la ley penal, cometido con vinovăție, no justificado e imputable a la persona que lo ha cometido" ${ }^{31}$.

En la base de esta definición de delito, según la Exposición de Motivos del Proyecto de Código Penal, se encuentran tanto el Código penal de $1936^{32}$ como las legislaciones penales europeas que, como la rumana, han optado por definir el delito. De modo que, el nuevo Código penal combina la tradición legislativa rumana correspondiente al período interbélico con las actuales tendencias legislativas europeas, como, por ejemplo: la alemana, la italiana o la suiza, sin perder de vista los avances doctrinales en materia penal propios del Derecho comparado.

En cuanto a la definición del delito, la versión inicialmente propuesta por la Comisión redactora ${ }^{33}$ en el Antepro-

31 Art. 15 "Trăsăturile esențiale ale infracțiunii. (1) Infracțiunea este fapta prevăzută de legea penală, săvârșită cu vinovăție, nejustificată și imputabilă persoanei care a săvârșit-o. (2) Infracțiunea este singurul temei al răspunderii penale."

32 De inspiración italo-francesa.

33 La Comisión encargada de elaborar el Anteproyecto de CP estuvo compuesta tanto por representantes del Ministerio de Justicia y Libertades Ciudadanas, como por prestigiosos penalistas, entre los que destacan: el 
yecto de Código penal no incluía vinovăţia entre sus características esenciales. Se trataba de una opción legislativa motivada en la necesidad de esclarecer las funciones que vinovăția debe cumplir en el marco del delito. Pues, según indica la Exposición de Motivos del Anteproyecto, "actualmente, el concepto de vinovăție 34 tiene dos aceptaciones, unánimemente admitidas; en primer lugar, vinovăția representa un subelemento subjetivo del tipo, contexto en el que aparece bajo la forma de intención, culpa o preterintencionalidad; y, en segundo lugar, aparece como categoría o elemento integrante del concepto de delito. En esta nueva reglamentación, vinovăția, en su primera aceptación está llamada a cumplir la misma función, esto es, de elemento integrante de la estructura interna del hecho típico, a través del cual se analiza la concordancia entre el hecho humano concreto y el modelo penal abstracto descrito por el Legislador en la norma de incriminación. Por lo que respecta su segunda aceptación, la nueva redacción del concepto de delito ha optado por sustituir el término vinovăție por un término distinto -imputabilidad-. Este cambio terminológico se ha operado, en primer lugar, para evitar confusiones terminológicas que se podrían dar entre vinovăție, en cuanto subelemento subjetivo típico, y vinovăție, en cuanto categoría dogmática integrante del concepto del delito ${ }^{35}$.

Con todo, los cambios propuestos por la Comisión redactora del Anteproyecto, en el sentido de prescindir del

Prof. Valerian Cioclei de la Facultad de Derecho de la Universidad de Bucarest; el Prof. Ilie Pasca de la Facultad de Derecho y Ciencias Administrativas de la Universidad "Andrei Saguna" de Constanța y el Prof. Florin Streteanu de la Facultad de Derecho de la Universidad "BabesBolyai" de Cluj-Napoca.

34 Vinovăție es un sustantivo femenino singular que se acompaña del artículo determinado (a) que se añade al final del sustantivo y que sustituye a la letra (e).

35 Apartado 2.4 de la Exposición de Motivos del Anteproyecto de Código Penal. 
concepto de vinovăție en la nueva definición del delito, no prosperaron y durante el proceso legislativo, a petición del Parlamento, se volvió a introducir vinovăţia entre las características esenciales del delito. De modo que, lejos de aportar claridad, la nueva definición legal de delito se erige en una inacabable fuente de debate y controversias dentro de la Doctrina penal rumana, pues tal como afirma cierto sector doctrinal, el art. 15 CPRO contiene un concepto de delito de importación, ajeno a la tradición penal rumana ${ }^{36}$.

\subsection{El concepto de delito en la Doctrina penal rumana}

La elaboración y aprobación del vigente Código Penal rumano ha marcado el inicio de un ferviente, y, por lo demás, necesario desarrollo doctrinal dirigido, principalmente, a hacer concordar ciertas instituciones, conceptos y nociones del Derecho Penal rumano ${ }^{37}$ con las actuales corrientes doctrinales europeas ${ }^{38}$. Por lo que respecta la Parte General del Derecho Penal rumano, uno de los ámbitos que más ha ocupado a la Doctrina penal ha sido el de la Teoría General del Delito. De modo que, el nuevo concepto legal de delito ${ }^{39}$, las categorías que lo integran, así como el significado y alcance de esas categorías, ha generado un intenso debate doctrinal que se ha materializado en una notable heterogeneidad de opiniones -que, a continuación, grosso modo, se esbozarán-.

36 RICEANU, J., "Analiza trăsăturilor esenţiale ale infracţiunii în legea penală română”, en Revista de Drept Penal, cit., pág.27.

37 Ya en el año 2008, el Prof. Streteanu ponía de manifiesto la necesidad de actualizar la doctrina penal rumana en lo que respecta la Teoría General del Delito, en el sentido de asumir la concepción tripartita de delito (Tipicidad, Antijuridicidad y Culpabilidad), llegando a hacer una proposición de lege lata en este sentido. Véase STRETEANU, F., Tratat de drept penal. Partea Generală, cit., págs. 332-333.

38 Desarrollo no exento de obstáculos debido a las tradicionales concepciones dogmáticas.

39 Definido en el art. 15 CPRO como aquel "hecho previsto por la ley penal, cometido con vinovăție, no justificado e imputable a la persona que lo ha cometido". 
Con respecto a la nueva definición legal del delito, la Doctrina penal rumana únicamente coincide en que la Tipicidad es la primera categoría integrante del concepto de delito, divergiendo sus opiniones en todo lo demás, esto es, tanto en cuanto a los elementos que componen la Tipicidad, como al resto de categorías dogmáticas que configuran el concepto de delito ${ }^{40}$.

\subsubsection{La Tipicidad y su relación con Vinovăția}

\section{a) Vinovăția como elemento subjetivo no típico ni culpa- ble (Teoría cuatripartita del concepto de delito)}

Partiendo de la idea de que en el marco de la Tipicidad se debe comprobar la concordancia entre un hecho concreto y el tipo penal abstracto ${ }^{41}$, la Doctrina penal rumana, de forma inmensamente mayoritaria ${ }^{42}$, entiende que en la Tipicidad únicamente se ha de comprobar la concurrencia de los elementos objetivos del tipo ${ }^{43}$, relegándose, de ese modo, la

40 Esta heterogeneidad de opiniones doctrinales gira tanto en torno al número de categorías dogmáticas que conforman el concepto de delito, como al alcance y significado de algunas de ellas.

41 Se trata del, así llamado, proceso de subsunción; proceso a través del cual, según QUINTERO OLIVARES, G., Parte General del Derecho Penal, Ed. Aranzadi, 4 a ed., Navarra, 2010, pág. 308, se comprueba "que una conducta humana encaja en una descripción legal del delito".

42 Por todos, PASCU, I., "Titlul I, Infracţiunea, Capitolul I, Dispoziţii generale", en Pascu Ilie (coord.), Noul cod penal comentat. Partea generală, Ed. Universul Juridic, $2^{\mathrm{a}}$ ed revăzuta si adăugită, Bucarest, 2014, pág. 115; MITRACHE, C./MITRACHE, C, Drept Penal român. Partea generală, cit., pág.137. En el mismo sentido, GORUNESCU, M., "Capitolul II, Infracţiunea și trăsăturile ei esenţiale”, en Mirela Gorunescu (coord.), Noul Cod penal pe inţelesul tuturor, Ed. Universul Juridic, Bucarest, 2015, pág. 32.

43 En el mismo sentido se pronuncia también STRETEANU, F./NIŢU, D., Drept Penal Partea Generală, Vol. I, cit., pág. 255, a pesar de que en un primer momento -STRETEANU, F./MOROȘANU, R., Instituţii şi infracţiuni în noul cod penal, Manual pentru uzul formatorilor SNG, Bucarest, 2010, págs. 38-39- afirmarán que en la Tipicidad se deben analizar tanto los elementos objetivos como los subjetivos, de modo que "el concepto de vinovăție que aparece en la definición de delito del art. 
comprobación de los elementos subjetivos a otra categoría dogmática, esto es, a la vinovăție ${ }^{44}$-entendida por algunos autores como actitud psíquica peligrosa del sujeto activo ${ }^{45}$. Así, según este sector doctrinal, en la Tipicidad se deben analizar los siguientes elementos: los sujetos, el objeto (material y jurídico), las condiciones de tiempo y lugar en las que se ha cometido el hecho, la acción u omisión, el resultado y la relación de causalidad ${ }^{46}$.

\section{b) Vinovăția como elemento subjetivo del tipo (Teoría tripartita del concepto de delito)}

Sin embargo, y manteniendo una posición diversa, otra corriente Doctrinal minoritaria, liderada por UDROIU, entiende que la Tipicidad, en cuanto primer elemento del delito, implica la correspondencia entre el hecho humano concreto (activo u omisivo) y "los elementos objetivos y subjetivos

15 CPRO, se refiere a la Vinovăția que la norma de incriminación prevé para la existencia del delito, bajo la forma de intención, preterintención o culpa".

44 Véanse, en este sentido, GHIGHECI, C., Drept Penal. Partea Generală, pág. 3, disponible en www.int-lex.ro/.../D REPT\%20PENAL\%20PARTEA\%20GENE [consultado el: 16/02/2017]. Según este autor, dado que el art. 15 CPRO menciona a la Tipicidad entre las características generales del delito, diferenciándola de la vinovăție, esta (la Tipicidad) no puede referirse más que a la concordancia entre los elementos objetivos del hecho concreto con el tipo penal; AMZA T., "Trăsăturile esențiale ale infracțiunii”, en Revista Doctrină și Jurisprudenţă, Núm. 1-2, 2016, pág.7. Disponible en www.mpublic.ro/ro/content/revista-doctrina-sijurisprudenta [consultado el: 27/02/2017]. Para este autor, la Tipicidad se revela como el resultado de la comparación realizada entre el contenido objetivo del hecho concreto y el tipo, relegándose, por lo tanto, el análisis del contenido subjetivo a otra categoría distinta a la tipicidad, concretamente, a la vinovăție.

45 AMZA T., "Trăsăturile esențiale ale infracțiunii", en Revista Doctrină și Jurisprudenţă, cit., pág. 8 .

46 En el mismo sentido, IVAN, M.C./IVAN, G., Cauzele justificative, Ed. Universul Juridic, Bucarest, 2016, pág. 16. Según estos autores, para que una conducta pueda ser calificada como típica, el contenido objetivo de la conducta ha de casar exactamente con el tipo. 
del tipo" ${ }^{47}$. Así, para este autor el análisis de la Tipicidad debe comprender: el objeto del delito (jurídico, es decir, el bien jurídico protegido y material o, lo que es lo mismo, el objeto de la acción), los sujetos (activo y pasivo), el aspecto objetivo (el verbum regens, el resultado, la relación de causalidad y el lugar y tiempo en que se ha cometido el hecho) y el aspecto subjetivo (dolo, culpa y preterintencionalidad).

Según UDROIU, la ubicación del proceso de análisis de los elementos subjetivos en la categoría de la Tipicidad se deduce claramente de lo dispuesto en el art. 16.1 CPRO que establece que "únicamente será constitutivo de delito el hecho cometido con la forma de vinovăție legalmente establecida"48. En el mismo sentido se pronuncia el Ministerio Fiscal esgrimiendo como argumento la voluntas legislatoris ${ }^{49}$ que, según la Exposición de Motivos del Anteproyecto de Código Penal en la forma en la que se envió al Parlamento por el Ministerio de Justicia ${ }^{50}$, era la de incluir los elementos subjetivos del tipo, es decir, vinovăția y sus formas, en la Tipicidad.

La consecuencia inmediata que se deriva de la inclusión de los elementos subjetivos, esto es, vinovăția y sus for-

47 UDROIU, M., Sinteze și Grile. Drept Penal. Parte Generală. Noul Cod Penal, Ed. C.H. Beck, Bucarest, 2014, pág. 38.

48 Del mismo argumento se sirven STRETEANU y NIȚU para afirmar justamente lo contrario. Según los citados autores, de lo dispuesto en el art. 16.1 CPRO "resulta inequívocamente la intención de extraer Vinovăția de entre los elementos integrantes de la tipicidad para transformarla en una categoría autónoma de la que no se hace depender la existencia del hecho previsto por la ley penal, sino la calificación del hecho como delictivo". STRETEANU, F./ NIȚU, D., Drept Penal. Partea Generală, Vol. I., cit., nota 5, pág. 254.

49 Ministerul Public. Parchetul de pe lângă Înalta Curte de Casație și Justiție, "Material Noul Cod Penal", págs. 15-17. Disponible en: www.mpublic.ro/ro/content7noile-coduri-note-de-studiu [consultado el:27/02/2017].

50 Disponible en: http://www.just.ro/Portals/0/Coduri/coduri_60309/ Expunere $\% 20 \mathrm{de} \% 20$ motive $\% 20$ Proiectul $\% 20$ Legii $\% 20$ privind $\% 20$ Codul $\% 20$ Penal- $\% 20$ forma $\% 20$ transmisa $\% 20$ Parlamentului.doc. [consultado el:3/03/2017]. 
mas -dolo, culpa y preterintencionalidad-en la Tipicidad, es la distinta configuración de la estructura de esta categoría y, sobre todo, de la estructura del concepto de delito, pues, desde esta perspectiva, el concepto dogmático de delito ya no estaría conformado por la concurrencia de cuatro categorías-Tipicidad, Vinovăție, Antijuridicidad e Imputabilidad-, sino, únicamente por tres, esto es, la Tipicidad -integrada por elementos objetivos y elementos subjetivos-, la Antijuridicidad y la Imputabilidad.

Hasta aquí hemos visto como el debate doctrinal en torno al concepto de delito versa sobre la vinovăție y su relación con la Tipicidad. La Doctrina penal rumana, de forma inmensamente mayoritaria, según hemos visto, propugna que vinovăția no integra la Tipicidad -que tan solo incluiría el tipo objetivo- extrayendo de esta primera categoría el tipo subjetivo, lo que a priori, al menos, acercaría a esta Tipicidad, así configurada, a la propia de la Teoría neoclásica del Concepto de Delito.

Por su parte, la segunda de las posiciones doctrinales analizadas, defendida por UDROIU, desde una concepción del delito cercana a las doctrinas finalistas, identifica vinovăţia con tipo subjetivo, lo que facilita, sin duda, la comprensión del concepto de delito y lo acerca a la concepción imperante en España -salvando las distancias-. Si bien, como vamos a ver, el sustento legislativo de esta postura es francamente débil.

\subsubsection{La Tipicidad: toma de postura}

Esta segunda tesis - defendida por UDROIU- tiene a su favor, tal y como esgrime el Ministerio Fiscal, que es más acorde con la interpretación auténtica que hace la Exposición de Motivos del Anteproyecto de Código Penal sobre el significado de los elementos integrantes del concepto de delito. Siendo cierto esto, sin embargo, no se puede pasar por alto que el Anteproyecto, tras su paso por el Parlamento, ha 
sufrido diversas modificaciones que, entre otras cuestiones, han afectado a la definición del delito. La Comisión Parlamentaria, como ya se ha advertido, reintrodujo ${ }^{51}$ vinovăția entre las categorías integrantes del concepto legal de delito ${ }^{52}$ -junto a la Tipicidad, Antijuridicidad e Imputabilidad- lo que significa que el actual sistema penal rumano adopta un concepto cuadripartito de delito ${ }^{53}$.

Por ello, el argumento según el cual la Exposición de Motivos del Anteproyecto de Código penal refuerza la configuración de la vinovăția como un elemento subjetivo del tipo y no como una categoría dogmática independiente, pierde gran parte de su peso, ya que, durante el proceso legislativo la propuesta de definición del concepto legal de delito realizada por la Comisión redactora en el Anteproyecto de Código no se mantuvo.

Fuera cual fuere la intención que latía en la génesis del concepto de delito propuesto por la Comisión redactora del Anteproyecto de Código penal, la labor interpretativa ha de ajustarse a lo que el Legislador penal, en cuanto representante de toda la sociedad, ha decidido plasmar en la Ley. Pues, tal como afirma ÁLVAREZ GARCÍA, la decisión de atribuir el poder normativo en materia penal al Legislador, y únicamente a él, "reside en la representatividad de aquel poder, en ser expresión no de una oligarquía sino de todo el pueblo" ${ }^{54}$. De modo que, apelando al significado político del principio de legalidad penal ${ }^{55}$ entendemos que el Anteproyecto elabo-

51 En contra de la propuesta del Anteproyecto de Código penal.

52 El proceso Legislativo del Proyecto de Código penal puede ser consultado en la web de la Cámara de los Diputados, en el enlace: http://www. cdep.ro/pls/proiecte/upl_pck.proiect?idp $=10255$.

53 Apartándose así de los sistemas penales de referencia a nivel europeo que contienen un concepto de delito secuencial tripartito.

54 ÁlVAREZ GARCÍA. F. J., Sobre el Principio de Legalidad, Ed. Tirant lo Blanch, Valencia, 2009, pág. 10.

55 Sobre el fundamento político del principio de legalidad véase, ARROYO ZAPATERO, L., "Principio de legalidad y reserva de ley en materia penal", en Revista Española de Derecho Constitucional, Año 3, Núm. 8, 
rado por el Ministerio de Justicia no puede, en ningún caso, representar la voluntas legislatoris, pues esta únicamente se pone de manifiesto cuando, siguiendo los cauces del proceso legislativo, el Anteproyecto llega en sede parlamentaria donde es debatido y, finalmente, votado y aprobado. Son esos debates parlamentarios en los que se pone de manifiesto "la opinión del total cuerpo social" 56 , los que configuran la verdadera voluntas legislatoris, y no el acto normativo proveniente de un Departamento del Gobierno. Como consecuencia, la voluntas legislatoris que se desprende del texto legal que define el concepto de delito -art.15 CPRO- es que en la Tipicidad se deben integrar, únicamente, elementos de carácter objetivo ${ }^{57}$ ya que, de los subjetivos se ocupa otra categoría dogmática, vinovăția $a^{58}$. En este sentido se pronuncian, también, STRETEANU/NIŢU, quienes, resignados afirman que "con pesar, debemos admitir que, en la actual reglamentación, la previsión del hecho en la ley penal se refiere solo a los elementos objetivos del tipo" ${ }^{59}$.

\subsubsection{Vinovăția}

Lo expuesto en líneas precedentes pone de manifiesto el gran debate doctrinal que gira en torno al segundo elemento

mayo-agosto, 1983, págs. 12-14. Disponible en: https://dialnet.unirioja. es/descarga/articulo/249711.pdf [última consulta: 22/06/2017].

56 ÁlVAREZ GARCÍA. F. J., Sobre el Principio de Legalidad, cit., pág.11.

57 Así, STRETEANU, F/ NIȚU, D., Drept Penal. Partea Generală, Vol. I, cit., pág. 255.

58 La exposición de motivos del Proyecto de Código en la forma en la que finalmente fue aprobado sigue afirmando, al igual que lo hacía la exposición de motivos del Anteproyecto, que en el marco de la Tipicidad se deben analizar tanto los elementos objetivos como los subjetivos. Ello, sin embargo, parece ser irrelevante, pues, según Streteanu -miembro integrante de la Comisión redactora del Anteproyecto- la exposición de motivos de proyecto "ha sido confeccionada en base al Anteproyecto, en la forma en la este fue presentado ante la Comisión parlamentaria (...).” STRETEANU, F/ NIȚU, D., Drept Penal Partea Generală, Vol. I., cit., pág. 255.

59 STReteAnU, F./ NIȚU, D., Drept Penal. Partea Generală, Vol. I, cit., pág. 255. 
del concepto de delito del art. 15.1 CPRO de 2009, vinovăția, tanto en lo que respecta su contenido y función, como en lo que respecta su ubicación en la estructura del delito.

a) Posición tradicional en torno al concepto de vinovăție

El tratamiento que tradicionalmente (esto es, antes de la promulgación del CPRO de 2009) venía recibiendo el concepto de vinovăția, tanto por parte de la Doctrina penal, como por parte de la Jurisprudencia rumana era el equivalente a la Culpabilidad -culpabilitate-, variando, sin embargo, su significado y alcance en función de la teoría desde la que se explicaba - psicológica o normativa ${ }^{60}$. Así, para los seguidores de la Teoría psicológica, mediante la culpabilidad o vinovăție, se comprobaba la relación psicológica existente entre el autor y su hecho, mientras que, para los partidarios de la Teoría normativa, la culpabilidad tenía el significado de reprochabilidad ${ }^{61}$.

b) Vinovăția en al CPRO de 2009

b)1. Vinovăţia como elemento bifacético

En la actualidad, la Doctrina penal rumana, en su inmensa mayoría, entiende que vinovăția, en su vertiente de categoría dogmática integrante del concepto de delito ${ }^{62}$, hace referencia a "la posición psíquica" ${ }^{63}$ (Teoría psicológica de la culpabilidad) que adopta el infractor respecto de su hecho y de las consecuencias que de él se derivan ${ }^{64}$, mientras que en

60 BUlAI, C., Manual de Drept Penal. Partea Generală, cit., págs., 154164.

61 Vid. PAȘCA, V., Drept Penal. Partea Generală, 4ª ed., Ed. Universul Juridic, Bucarest, 2015, págs. 156-158.

62 En contra UDROIU, M., Sinteze și Grile. Drept Penal. Parte Generală. Noul Cod Penal, cit., pág. 51.

63 PASCU, I., "Titlul II. Infracţiunea. Capitolul I. Dispoziţii generale.", en Pascu Ilie (coord.) Noul cod penal comentat, Partea generală, cit., pág. 116.

64 MiTRACHE, C./ MITRACHE, C, Drept Penal român. Partea generală, cit., pág. 137; SIMIONESCU E.G./DUNGAN P., Funcționarul public și 
su vertiente de subelemento subjetivo ${ }^{65}$ hace referencia a las formas de vinovăție: dolo, culpa y preterintencionalidad ${ }^{66}$.

Otro sector doctrinal, con fundamentos en la Teoría normativa de la culpabilidad ${ }^{67}$, entiende que en el marco de esta categoría (vinovăție) se lleva a cabo un doble proceso. Por un lado, se efectúa el análisis in concreto ${ }^{68}$ de la culpabilitate, esto es, verificándose la concordancia entre la forma de vinovăție con la que se ha cometido el hecho concreto y la forma de vinovăție típicamente prevista (dolo, culpa o preterintencionalidad). Y, por otro, se comprueba si el sujeto podía haber adecuado su comportamiento a la norma (esto es, que el sujeto no haya actuado a causa de una fuerza irresistible o caso fortuito) y si conocía la antijuridicidad de su hecho ${ }^{69}$.

b)2. Vinovăția como elemento subjetivo del tipo

Una tercera postura doctrinal, liderada por UDROIU, - a la que hemos tenido oportunidad de referirnos al tratar la Tipicidad- entiende, apelando a lo establecido en el art. 16.1

răspunderea penală in noul Cod penal și in legile speciale, Ed. Hamargiu, Bucarest, 2016, pág. 68.

65 En la base de este tratamiento paralelo que recibe el concepto de vinovăție late la tradicional Teoría general del delito compuesta por el concepto de delito y el contenido de la infracción. Así, desde la perspectiva del concepto de delito, Vinovăția es una categoría dogmática, mientras desde la perspectiva del contenido de la infracción, Vinovăția es un subelemento subjetivo.

66 PASCU, I., "Titlul I, Infracţiunea, Capitolul I, Dispoziţii generale”, en Pascu Ilie (coord.) Noul cod penal comentat. Partea generală, cit., pág. 122.

67 Siguiendo la tradicional Teoría general del delito de dos elementos.

68 Según ROTARU, ya en el marco de la tipicidad se hace una evaluación in abstracto de los elementos subjetivos, esto es, una mera detección de las formas de "vinovăție". ROTARU, C., "Cauzele justificative și cauzele de neimputabilitate", en Consiliul Superior al Magistraturii. Institutul Național al Magistraturii, Conferințele Noului Cod Penal, cit., pág.14.

69 ROTARU C., "Cauzele justificative și cauzele de neimputabilitate", en Consiliul Superior al Magistraturii. Institutul Național al Magistraturii, Conferințele Noului Cod Penal, cit., pág.14. 
$\mathrm{CPRO}^{70}$, que vinovăţia es un subelemento subjetivo del tipo, lo que significa que, para este autor, el concepto de vinovăție no tiene el significado de culpabilitate, sino de elemento subjetivo del tipo ${ }^{71}$.

b)3. Vinovăția como categoría dogmática diferente a la Tipicidad y a la Culpabilidad

Como un hibrido entre unas tesis y otras destaca la sostenida por STRETEANU/NITU, según quienes, vinovăția -segunda categoría integrante del concepto de delito- tiene como contenido el elemento subjetivo del delito en cuyo contexto se ha de analizar la forma de vinovăție con la que el sujeto activo ha actuado, esto es: con dolo, culpa o preterintencionalidad..$^{72}$ Así, desde la óptica de los citados autores, vinovăția no debe ser entendida en clave de culpabilidad -tal como lo hace la Doctrina de forma inmensamente mayoritaria $^{73}$-, sino, como una categoría dogmática propia - diferente tanto de la Tipicidad como de la Culpabilidad-.

ROTARU ${ }^{74}$ profundiza en la tesis que concibe la Tipicidad como "exclusivamente objetiva" y nos ofrece una

70 Establece el art. 16.1 CPRO: "únicamente será constitutivo de delito el hecho que se haya cometido con la forma de vinovăție legalmente establecida".

71 UDROIU, M., Sinteze și Grile. Drept Penal. Parte Generală. Noul Cod Penal, cit., págs. 51-57.

72 StreteAnU, F./NIŢU, D., Drept Penal. Partea Generală, Vol. I., cit., pág. 255.

73 En contra, PAȘCA, V., Drept Penal. Partea Generală, cit., págs. 157-158, quien afirma que, en vista de que el art. 16 CPRO, de 2009, define las formas de vinovăție en términos propios de la Teoría psicológica de la culpabilidad, no cabe más remedio que concebir esta en los mismos términos.

74 ROTARU C., "Cauzele justificative și cauzele de neimputabilitate", en Consiliul Superior al Magistraturii. Institutul Naţional al Magistraturii, Conferințele Noului Cod Penal, pág. 13. Disponible en: http://www.inmlex.ro/fisiere/d_176/Rezumatele\%20conferintelor\%20NCP.pdf. (consultado el: 16/02/2017) y, también, ROTARU C., "Definiția infracțiunii în noul Cod penal”, en Curierul judiciar, Num. 7, București, 2014, pasim. 
nueva perspectiva cuando afirma que el Legislador penal, en el art. 15.1 CPRO de 2009, ha optado por descomponer una de las categorías del delito, Culpabilitatea ${ }^{75}$, en sus elementos integrantes. Así, el dolo y la culpa pasan a formar parte de una categoría independiente: vinovăția, mientras que la responsabilidad, el conocimiento de la antijuridicidad del hecho y la exigibilidad de otra conducta son, ahora, elementos integrantes de otra categoría, que se denomina Imputabilitate.

Como se puede observar, el segundo elemento del concepto de delito del art. 15.1 CPRO de 2009, vinovăţia, mantiene a la Doctrina penal rumana más que dividida. Pues mientras que un sector de la Doctrina considera que vinovăția es un elemento bifacético relacionado con la Culpabilidad, otro considera que es un elemento subjetivo que se integra en la Tipicidad y otro que se trata de una categoría dogmática que contiene los elementos subjetivos del tipo, pero que no se identifica ni con la Tipicidad, ni con la Culpabilidad, sino que es una categoría dogmática independiente.

\subsubsection{Vinovăția: toma de postura}

En nuestra opinión, el Legislador penal rumano, al configurar el concepto de delito en el art. 15 CPRO, ha optado, tal como sostiene ROTARU ${ }^{76}$, por descomponer una de sus categorías -la Culpabilidad ${ }^{77}$, cuyos elementos integrantes eran: el dolo, la culpa y la imputabilidad- para, posteriormente reubicar sus elementos integrantes en otras dos categorías independientes, a saber, en la vinovăție y en la

75 La autora utiliza el concepto de "culpabilitate" como sinónimo del concepto de "culpabilidad".

76 ROTARU C., "Cauzele justificative și cauzele de neimputabilitate", en Consiliul Superior al Magistraturii. Institutul Național al Magistraturii, Conferințele Noului Cod Penal, pág. 13. Disponible en: http://www.inmlex.ro/fisiere/d_176/Rezumatele $\% 20$ conferintelor\%20NCP.pdf. [consultado el: 16/02/2017].

77 Sobre la Teoría psicológica de la culpabilidad véase, entre otros, ROXIN C., Derecho Penal Parte General, Tomo I, Fundamentos. La estructura de la Teoría del Delito, Ed. Civitas, Madrid, 1997, págs.794 y ss. 
Imputabilidad (Imputabilitate), respectivamente. Así, en un intento de abandonar la clásica Teoría psicológica, según la cual el dolo y la culpa aparecían como formas de culpabili$\mathrm{dad}^{78}$, el Legislador penal rumano, bajo la denominación de vinovăție ha introducido una nueva categoría en la estructura del delito - diferente de la Culpabilidad ${ }^{79}$ - que contiene los elementos subjetivos del delito: el dolo, la culpa o, mejor dicho, la imprudencia ${ }^{80}$ y la preterintencionalidad.

Así, en nuestra opinión, el dolo ${ }^{81}$, la imprudencia ${ }^{82}$ y la preterintencionalidad ${ }^{83}$ son formas o títulos de imputación y vinovăția, la categoría en cuyo seno se lleva a cabo el proceso de comprobación de la forma subjetiva con la que se ha cometido el hecho concreto y la forma legalmente prevista

78 Vid., por todos, DE LA CUESTA AGUADO, P.M., Culpabilidad, Exigibilidad y razones para la exculpación, Ed. Dykinson, Madrid, 2003, pág.30.

79 ROTARU, por el contrario, sostiene que, Vinovăția es culpabilidad -en cuanto categoría dogmática-, habiéndose extraído de su estructura uno de sus elementos, esto es, la imputabilidad, que a su vez constituye una categoría configuradora del concepto de delito. ROTARU C., "Cauzele justificative și cauzele de neimputabilitate", en Consiliul Superior al Magistraturii. Institutul Național al Magistraturii, Conferințele Noului Cod Penal, cit., pág.14.

80 En vista de que "la culpa" no es una forma de culpabilidad, sino un elemento subjetivo que se ubica en una categoría dogmática distinta, en la Vinovăție, consideramos oportuno sustituir dicho concepto, a la hora de traducirlo, por el de "imprudencia".

81 Dispone el art. 16.3 CPRO:" [e]l hecho habrá sido cometido con intención cuando el sujeto: a) previó el resultado de su actuar, queriendo y buscando su producción; b) previó el resultado de su actuar y, a pesar de no buscarlo, aceptó la posibilidad de su producción".

82 Según lo dispuesto en el art 16.4 CPRO: "[e]l hecho habrá sido cometido con imprudencia cuando el sujeto: a) previó el resultado de su hecho, no le aceptó, pero confió en su no producción; b) no previó el resultado que su hecho produjo, a pesar de que podía y debía haberlo previsto". Como se puede observar, el concepto de culpa que se maneja es el propio de la Teoría psicológica de la culpabilidad.

83 Habrá preterintencionalidad, según el art. 16.5 CPRO cuando, como consecuencia de la realización de una acción u omisión dolosa, se produzca un resultado más grave que el pretendido por el autor a causa de su actuar imprudente. 
en el tipo penal abstracto. De este modo, para que un hecho sea delito, además de reunir todos los elementos objetivos típicos, el título con el que se haya cometido ha de coincidir exactamente con el título de imputación subjetivo legalmente establecido en el tipo penal abstracto. Ahora bien, en caso de incongruencia, la Tipicidad no se verá afectada -en el sentido de excluirse- pues la conducta, objetivamente típica, pude ser constitutiva de otro tipo de ilícito, distinto al penal ${ }^{84}$. Ello significa que, a pesar de faltar los elementos subjetivos del delito (dolo, imprudencia o preterintencionalidad) el hecho seguirá siendo objetivamente típico y "el Legislador, si lo considera necesario, puede imponer una medida de seguridad" 85 al autor de este. En este sentido se pronuncian, entre otros, STRETEANU/NIŢU, quienes entienden que, aun cuando se constate que el hecho (objetivamente típico) no ha sido cometido con vinovăție, se deberá seguir con el análisis de la Antijuridicidad, pues, según lo dispuesto en el art. 107.2 CPRO de $2009^{86}$, "la imposición de medidas de seguridad depende únicamente de la tipicidad y del carácter antijurídico del hecho, siendo irrelevante, en este sentido, vinovăția"87.

Si esto es así, cabe preguntarse hasta qué punto vinovăția es la segunda categoría del concepto de delito o hasta qué punto el concepto de delito del art. 15.1 CPRO de 2009 es un concepto secuencial. Si entendemos, pues, que el art. 15.1 CPRO de 2009 contiene un concepto secuencial de delito, vinovăția no pude ser la segunda categoría dogmática, sino, en todo caso, la tercera o la cuarta.

84 IVAN, M.C./IVAN, G., Cauzele justificative, cit., pág. 17.

85 IVAN, M.C./IVAN, G., Cauzele justificative, cit., pág. 17.

86 Art. 107.2 CPRO de 2009: "Las medidas de seguridad se impondrán a la persona que haya cometido un hecho típico y antijurídico."

87 STReteAnU, F./ NIȚU, D., Drept Penal. Partea Generală, Vol. I., cit., pág. 349. 


\subsubsection{La Antijuridicidad en el CPRO DE 2009. Especi- al referencia al estado de necesidad}

I. Para que una conducta sea constitutiva de delito no basta con que sea típica, sino que, además, tiene que ser antijurídica e imputabilã -culpable-. Así, el tercer elemento del concepto de delito, según la definición contenida en el art. 15 CPRO, es la Antijuridicidad. Ahora bien, que el Legislador penal rumano, haya situado la Antijuridicidad, después de la Tipicidad y de vinovăție (en el art. 15.1 CPRO), no quiere decir que, efectivamente, esta sea la tercera categoría dogmática del concepto del delito ${ }^{88}$, sino, más bien la segunda, pues, como acabamos de advertir en líneas precedentes, tal consideración comportaría negar el carácter secuencial del concepto de delito.

La Antijuridicidad representa la contrariedad de un hecho -objetivamente típico- con el Ordenamiento Jurídi$\mathrm{co}^{89}$; contrariedad que se constata mediante un juicio negativo, es decir, comprobando que -el hecho típico- no está justificado por la concurrencia de alguna causa de justificación. Así, según el art. 18 CPRO de 2009, "no constituirá delito el hecho típico en el que concurra alguna de las causas de justificación previstas por la Ley".

El Capítulo II, del Título II, del CPRO de 2009, bajo el rótulo Cauzele justificative -"Las causas de justificación"-, designa las causas de justificación en el Derecho penal rumano: la legítima defensa (art. $19 \mathrm{CPRO}^{90}$ ), el estado de

88 En este sentido se pronuncia, también, STANILĂ, L., "Definiția infracțiunii in Noul Cod penal și implicațiile sale", en Analele Universității de Vest din Timişoara, Núm. 1, 2012, págs. 42-44. Según la autora, la Antijuridicidad sería el segundo elemento del delito, en tanto que Vinovăția -en cuanto expresión de la culpabilidad-sería el cuarto.

89 STReteAnU, F./ NIȚU, D., Drept Penal Partea Generală, Vol. I., cit., pág. 349.

90 Según el art. 19. 2 CPRO “actuará en legítima defensa el que obre para repeler un ataque material, directo, inmediato e ilegítimo que suponga un peligro para sí mismo, para terceros o sus derechos o para un interés 
necesidad (art. 20 CPRO), el ejercicio de un derecho o cumplimiento de un deber (art. 21 CPRO) y el consentimiento (art. 22 CPRO).

Como se puede observar, a diferencia del Código penal español de 1995 (y del ya derogado CPRO de 1968 ${ }^{91}$ ), el CPRO de 2009 establece expresamente cuales son las causas de justificación, separándolas así de las causas de inimputabilitate o, lo qué es lo mismo, de las causas e exclusión de la culpabilidad -que se encuentran contempladas en el Capítulo III, del Libro II CPRO-.

II. Entre las causas de justificación del Capítulo II se encuentra el estado de necesitad, lo que no deja de ser llamativo en vista de que su concurrencia no excluye la responsabilidad civil ${ }^{12}$-asemejándose, desde este punto de vista, a las causas de inimputabilitate del Capítulo III, del Libro II-. No obstante, en vista de lo dispuesto en el art. 20.1 CPRO de 2009- "[e]l hecho típico cometido en estado de necesidad estará justificado"-no cabe más afirmar su carácter de causa de justificación ${ }^{93}$.Consecuencia inmediata de su inclusión entre las causas de justificación es que frente a un ataque en estado de necesidad no cabe actuar en legítima defensa ${ }^{94}$. Además, al ser el estado de necesidad una causa de justificación y no una causa de inimputabilitate, sus efectos se extienden, también, a los posibles partícipes ${ }^{95}$.

general, siempre que la defensa sea proporcional a la gravedad del ataque."

91 El CPRO de 1968 no distinguía entre causas de justificación y causas de inimputabilidad, contemplándolas de manera conjunta en los arts. 4451, bajo el rótulo: "Las causas que excluyen el carácter penal del hecho". Véase, IVAN, M.C./IVAN, G., Cauzele justificative, cit., págs. 36-39.

92 Vid., STRETEANU, F./ NIȚU, D., Drept Penal. Partea Generală, Vol. I., cit., pág. 391.

93 STRETEANU, F./ NIȚU, D., Drept Penal. Partea Generală, Vol. I., cit., pág. 375.

94 PASCU, I., "Titlul I, Infracţiunea, Capitolul I, Dispoziţii generale", en Pascu Ilie (coord.) Noul cod penal comentat. Partea generală, cit., pág. 144.

95 De conformidad con lo dispuesto en el art. 107.2 CPRO de 2009, a los sujetos que actúen en estado de necesidad no se les podrán aplicar 
Actúa en estado de necesidad, según el art. 20.2 CPRO de 2009, "la persona que realiza el hecho típico para salvar, de un peligro inmediato que no puede ser evitado de otra manera, su vida, integridad corporal o la salud de un tercero, un bien importante para él o para un tercero o un interés general, siempre que las consecuencias de su actuar no sean más graves que las que se hubieran producido en caso de no haber actuado".

Varias son las cuestiones que plantea el estado de necesidad del art. 20 CPRO de 2009, sin embargo, su estudio excedería con mucho los límites y objetivos del presente trabajo de investigación. Así, de entre los diversos elementos del estado de necesidad, nuestra atención se va a centrar en el "interés general" en cuanto objeto susceptible de salvar en estado de necesidad.

a) El "interés general" como objeto de la acción salvadora

Antes de acercarnos al significado del concepto de "interés general" del art. 20 CPRO de 2009, cabe advertir, no obstante, que el mencionado "elemento" no es privativo del estado de necesidad, pues, según el art. 19.1 CPRO, la legítima defensa cabe, también, frente a un ataque que suponga un peligro para un "interés general".

La opción del Legislador penal de 2009 de incluir entre los objetos defendibles en legítima defensa o susceptibles de salvar en estado de necesidad el "interés general" genera opiniones encontradas entre la doctrina penal rumana. Así, mientras que algunos autores consideran que se trata de un concepto excesivamente vago ${ }^{96}$, necesitado de concreción,

medidas de seguridad, ya que el presupuesto necesario para ello es que hubieran cometido un hecho típico y antijurídico. Véase, GĂLĂŢEANU, E. O., Teme de Drept Penal General, Ed. Pro Universitaria, Bucarest, 2015, pág. 51.

96 STReTEAnU, F./ NIŢU, D., Drept Penal Partea Generală, Vol. I., cit., pág. 362 . 
otros -sin negar su carácter unívoco- consideran que "desde el momento en el que se trata de algo que interesa a toda una colectividad o a toda la sociedad, el interés general es legítimo por su propia naturaleza" ${ }^{97}$.

Relacionando el concepto de "interés general" con el concepto de "público"-definido en el art. 176 CPRO de $2009^{98}$ - el "interés general", en opinión de un sector de la Doctrina penal rumana, vendría a representar "el interés del Estado u otras personas jurídicas de derecho público" "99; en tanto que, para otro, el "interés general" podría representar una situación, relación o actividad que atañe a una organización pública ${ }^{100}$.

Otros autores, como, PAȘCA o STRETEANU/NIŢU, en cambio, consideran que, junto a los intereses de las instituciones públicas o de las personas jurídicas que administran o explotan bienes de propiedad pública, integran el "interés general" -al que se refieren los arts. 19 y 20 CPRO de 2009 también, "los intereses propios de las autoridades públicas, así como, los intereses privados de los ciudadanos o de la colectividad" "101. Así, según STRETEANU/NIŢU, el concepto de "interés general" es más amplio que el concepto de "público" del art. 176 CPRO de 2009 con el que, además, no cabe relacionarlo, pues no ha sido esa la voluntad del Legis-

97 PAȘCA, V., Drept Penal. Partea Generală, cit., pág. 206.

98 Según el referido precepto penal "[e]l termino público hace referencia a todo lo relativo a autoridades públicas, instituciones públicas u otras personas jurídicas que administran o explotan bienes de propiedad pública".

99 Así, PASCU, I., "Titlul I, Infracţiunea, Capitolul I, Dispoziţii generale", en Pascu Ilie (coord.) Noul cod penal comentat. Partea generală, cit., pág. 144; DIMA, T., Drept Penal. Partea Generală, $3^{\mathrm{a}}$ ed., Ed. Hamargiu, Bucarest, 2014, pág. IVAN, M.C./IVAN, G., Cauzele justificative, cit., pág. 97.

100 Así, MitRACHE, C./ MITRACHE, C, Drept Penal român. Partea generală, cit., pág. 181.

101 PAȘCA, V., Drept Penal. Partea Generală, cit., págs. 206-207. 
lador ${ }^{102}$. El "interés general" hace referencia, afirman STRETEANU/NIŢU, a un número indeterminado de personas, a una colectividad que puede representar un determinado grupo social, étnico o religioso o al Estado mismo o a la sociedad en su conjunto ${ }^{103}$.

En vista de la amplitud del concepto de "interés general", parte de la Doctrina penal rumana propugna por condicionar la admisibilidad del estado de necesidad a intereses generales determinados ${ }^{104}$. Así, según ANTONIU, no podrían constituir objeto de salvación o defensa el orden público in abstracto, el medio ambiente o el Estado de Derecho cuando el peligro o el ataque a los mismos no se concrete, además, en la lesión o puesta en peligro de un bien jurídico individual ${ }^{105}$.

Por el contrario, otro sector de la Doctrina considera que pueden constituir objeto de la acción salvadora o defensora tanto la seguridad del Estado, el orden público o la capacidad de defensa del Estado ${ }^{106}$, so pretexto de que "el interés general es legítimo por su propia naturaleza" 107 .

En opinión de STRETEANU/NIŢU, el “interés general" general, a efectos del art. 19 y 20 CPRO de 2009, efectivamente, debe de ser uno concreto, lo que no significa, sin embargo, que el ataque o peligro en el que este se encuentre se tenga que materializar en la lesión o puesta en peligro de un bien jurídico individual, bastando, pues, la afectación a

102 StReteAnU, F./NIȚU, D., Drept Penal. Partea Generală, Vol. I., cit., pág. 362.

103 STRETEANU, F./ NIŢU, D., Drept Penal. Partea Generală, Vol. I., cit., pág. 362.

104 Así, IVAN, M.C./IVAN, G., Cauzele justificative, cit., pág. 97.

105 ANTONIU, G., Vinovăția penală, ed. Academiei Române, Bucarest, 1995, pág. 278.

106 Así, entre otros, LEFTERACHE, L. V., Drept Penal. Partea Generală. Curs pentru studenţii anului II, Ed. Hamargiu, Bucarest, 2016, pág. 195.

107 PAȘCA, V., Drept Penal. Partea Generală, cit., pág. 206. 
un bien jurídico de corte colectivo como la salud pública o la seguridad viaria ${ }^{108}$.

b) "El interés general": toma de postura

Cualquiera que fuere el significado del concepto de "interés general"-es decir, el que se corresponde con el concepto "público" del art. 176 CPRO de 2009 o el extensivo que, junto a "lo público", incluye, también, los intereses colectivos privados-e independientemente de su grado de concreción, lo cierto es que se trata de un concepto excesivamente amplio, ya que, prácticamente, cualquier interés supraindividual puede ser considerado "interés general" y puede, por tanto, ser objeto de defensa -en la legítima defensa- u objeto de la acción salvadora -en el estado de necesidad-.

De lege ferenda consideramos que, en vista de vaguedad y ambigüedad del concepto de "interés general" y dado el carácter autoritario que confiere al Derecho penal rumano -pues, como se ha visto, este concepto justifica o exculpa la lesión de bienes jurídicos en pos de la defensa del orden público-el Legislador penal rumano debería reformar los arts. 19 y 20 del CPRO de 2009, en el sentido de suprimir el "interés público" como objeto defendible en legítima defensa o salvable en estado de necesidad.

\subsubsection{Imputabilitatea}

Según hemos visto, el art. 15 CPRO de 2009, dispone que constituirá delito el hecho previsto en la ley penal, cometido con vinovăție, no justificado e imputable a la persona que lo haya ejecutado. Así, la imputabilidad o imputabilitatea es, pues, el último elemento que integra el concepto de delito del art. 15 CPRO de 2009.

Debido a que, tradicionalmente ${ }^{109}$, en el Derecho penal rumano, el concepto de imputabilitate y el de vinovăție 108 STRETEANU, F./NIŢU, D., Drept Penal. Partea Generală, Vol. I., cit., pág. 362.

109 Es decir, antes de la promulgación del CPRO de 2009. 
se utilizaban como sinónimos del de "culpabilidad" -en el sentido de la Teoría psicológica ${ }^{110}$, la actual Doctrina penal rumana tiene opiniones encontradas en torno a su significado actual. Así, en función de la Teoría General del Delito desde la que se aborde ${ }^{111}$, imputabilitatea puede significar una cosa u otra. Para los seguidores de la Teoría psicológica del concepto de delito, imputabilitatea es la atribución física y psíquica -con vinovăție $e^{112}$ - de un hecho a su autor ${ }^{113}$. Desde esta concepción doctrinal, vinovăția e imputabilitatea son términos que hacen referencia a una misma realidad ${ }^{114}$.

Ello, ha llevado a un sector de la Doctrina a firmar que "la inclusión de la imputabilidad entre las categorías dogmáticas que integran el concepto de delito aparece como una tautología, pues vinovăția ya ha sido mencionada entre las características esenciales del delito, y la imputabilidad objetiva ya se encuentra definida a través del elemento material del hecho que incluye la relación de causalidad entre acción (omisión) y el resultado" ${ }^{115}$.

PASCU, por su parte, entiende que, de acuerdo con la concepción psicológica de vinovăție -acogida en el CPRO de 2009-, imputabilitatea, en cuanto categoría dogmática inte-

110 STRETEANU, F./NIȚU, D., Drept Penal Partea. Generală, Vol. I., cit., pág. 408.

111 La tradicional, construida en base a los dos grandes elementos: el concepto de delito y el contenido de la infracción o la moderna-seguida por la mayoría de los sistemas europeos-.

112 ANTONIU, G., "Unele reflecţii asupra conceptului de incriminare si conceptului de infracţiune", en Revista de Drept Penal, Núm. 4, Año XVII, octubre-diciembre, 2010, Bucarest, pág. 25.

113 PASCU, I., "Titlul I, Infracţiunea, Capitolul I, Dispoziţii generale”, en Pascu Ilie (coord.) Noul cod penal comentat, Partea generală, cit., pág. 118.

114 Véase en este sentido, PASCU, I., "Titlul I, Infracţiunea, Capitolul I, Dispoziţii generale”, en Pascu Ilie (coord.) Noul cod penal comentat, Partea generală, cit., pág.119.

115 ANTONIU, G., "Unele reflecţii asupra conceptului de incriminare si conceptului de infracţiune", en Revista de Drept Penal, cit., pág. 25. 
grante del concepto de delito, no puede ser concebida como un elemento de la vinovăție, sino como una consecuencia de su efectiva concurrencia, pues, solo un hecho típico y antijurídico que, además, haya sido cometido con vinovăție se podrá imputar, en su caso, a su autor ${ }^{116}$. De modo que, para PASCU, imputabilitatea presupone vinovăţia o, lo que es lo mismo, vinovăția condiciona la imputabilidad. El concepto de imputabilitate, según el autor, "no se debe confundir con el de responsabilidad, y, tampoco, con el de vinovăție (culpabilitate), a pesar de que en ciertos contextos puedan aparecer como sinónimos" ${ }^{117}$.

Para STRETEANU/NIŢU ${ }^{118}$, imputabilitatea, sin embargo, es lo que, desde la perspectiva de la Teoría General del Delito de corte germana, es la culpabilidad -en el sentido de la Teoría normativa-. Así, para los citados autores - cuya opinión, por lo demás, compartimos- el concepto de imputabilitate y el de vinovăție del art. 15 CPRO, no son sinónimos y, por tanto, no hacen referencia a una misma realidad. Pues, mientras que vinovăția es aquella categoría dogmática integrada por el elemento subjetivo del delito -en cuyo seno se comprueba el título de imputación subjetiva-, imputabilitatea es la categoría dogmática a través de la cual se imputa -se reprocha- al agente la comisión del hecho típico y antijurídico.

Ahora bien, para que ese hecho le pueda ser imputado o reprochado al agente, este deberá cumplir una serie de requisitos. En primer lugar, deberá tener capacidad de culpabilidad -es decir, deberá ser responsable-, en segundo lugar, deberá conocer el carácter antijurídico de su hecho y, finalmente, este deberá haber podido adaptar su comportamiento a la norma - exigibilidad de otra conducta-.

116 PAȘCA, V., Drept Penal. Partea Generală, cit., pág. 156.

117 PAȘCA, V., Drept Penal. Partea Generală, cit., pág. 156.

118 STRETEAnU, F./NIŢU, D., Drept Penal Partea. Generală, Vol. I., cit., págs. 410-411. 
Las causas de inimputabilitate están expresamente previstas en el Capítulo III, del Título II, del Código penal, bajo el rótulo Cauzele de neimputabilitate (Las causas de exclusión de la culpabilidad). Así, en función del elemento sobre el que estas recaigan se distingue ${ }^{119}$ entre: causas que anulan la capacidad intelectiva del autor, esto es, la irresponsabilidad, la intoxicación y la minoría de edad ${ }^{120}$ y causas que anulan la capacidad volitiva, es decir, la fuerza irresistible, la coacción moral, el exceso no-imputable, el caso fortuito y el error ${ }^{121}$. La concurrencia de cualquiera de las anteriores causas comporta inimputabilitatea del hecho a su autor, manteniéndose, sin embargo, las otras características esenciales del delito. En opinión de PAȘCA, no obstante, inimputabilitatea excluye vinovăția ${ }^{122}$. Ello significa que, al sujeto que hubiere cometido un hecho típico y antijurídico, con vinovăție o sin vinovăție, pero en presencia de alguna de las causas de inimputabilitate, no se le podrá aplicar una pena, sino, todo lo más, una medida de seguridad ${ }^{123}$.

119 Vid., en este sentido, STRETEANU, F/NIŢU, D., Drept Penal. Partea Generală, Vol. I., cit., págs. 408-413.

120 En el Derecho penal rumano, según lo dispuesto en el art. 27 en relación con el art. 113 CPRO, los menores de entre 14 y 16 años serán penalmente responsable, a condición de probar que han actuado con discernimiento, de modo que, la edad que marca la posibilidad de exigir responsabilidad penal, sin condiciones, es la de 16 años.

121 El Legislador penal rumano ha decidido ubicar en el mismo precepto -art. 30 CPRO- tanto el error de tipo como el error de prohibición. En contra de lo que puede parecer, el error sobre los elementos constitutivos de la infracción (error de tipo) no es una causa de inimputabilidad, pues sus efectos se proyectan sobre el elemento subjetivo del injusto, Vinovăția. En contra, UDROIU, M., Sinteze și Grile. Drept Penal. Parte Generală. Noul Cod Penal, cit., pág.91, quien entiende que tanto el error sobre la tipicidad como el error sobre la antijuridicidad operan como causas de inimputabilidad.

122 PAȘCA, V., Drept Penal. Partea Generală, cit., pág. 223.

123 IVAN, M.C./IVAN, G., Cauzele justificative, cit., pág.18 


\section{A modo de conclusión}

El art. 15 CPRO de 2009 define el delito como aquel hecho previsto por la ley, cometido con vinovăție, no justificado e imputable a la persona de su autor.

La Doctrina penal rumana, de forma inmensamente mayoritaria, considera que el art. 15 CPRO de 2009 contiene un concepto cuatripartito de delito. Las cuatro categorías que integran el delito, hemos visto, son la Tipicidad, Vinovăția, la Antijuridicidad e Imputabilitatea. Hemos visto, también, que uno de los elementos del delito que más controversias genera entre la Doctrina penal rumana es Vinovăția. Así, la Doctrina penal mayoritaria (con base en la tradicional Teoría General del Delito compuesta por las características esenciales de la infracción -lo que equivaldría al concepto de delito- y el contenido de la infracción -lo que equivaldría a la Tipicidad-) concibe Vinovăția como un elemento bivalente. En consecuencia, desde la perspectiva del concepto de delito, Vinovăția es concebida como una categoría dogmática y hace referencia a la Culpabilidad, mientras, desde la perspectiva del contenido de la infracción, Vinovăția es concebida como un subelemento subjetivo que se ubica en la Tipicidad, pero cuyo análisis, no obstante, se realiza, in abstracto .

Otro sector de la Doctrina penal rumana, abandonando la tradicional Teoría General del Delito -construida sobre el contenido de la infracción y las características esenciales del delito- concibe Vinovăția como una categoría dogmática distinta tanto de la Tipicidad como de la Culpabilidad, en cuyo seno se lleva a cabo la verificación del elemento subjetivo del delito.

Este debate doctrinal en torno al significado, alcance y ubicación sistemática de uno de los elementos del delito -Vinovăția- pone de manifiesto las grandes dificultades ante las que se encuentra la Dogmática penal rumana y el gran esfuerzo que la Doctrina está haciendo para superarlas y armonizar el sistema penal rumano con las construcciones 
teóricas y los sistemas penales de los otros Estados Miembros de la UE.

En nuestra opinión, el actual concepto legal de delito no puede ser explicado desde la Teoría General del Delito de dos elementos, pues, como se ha visto, conduce a resultados poco satisfactorios. Por ello, consideramos acertada la postura de quienes, como STRETEANU/NIŢU, abordan el concepto de delito desde la Teoría General del Delito de corte germano. No obstante, a diferencia de los citados autores, a nuestro juicio, Vinovăția, no puede ocupar la segunda posición dentro de la estructura del concepto de delito, pues, ello supondría negar el carácter secuencial del delito.

\section{BIBLIOGRAFÍA}

ÁlVAREZ GARCÍA. F. J., Sobre el Principio de Legalidad, Ed. Tirant lo Blanch, Valencia, 2009.

AMZA T., "Trasaturile esentiale ale infractiunii", en Revista Doctrina si Jurisprudenta, No 1-2, 2016.

ANTONIU, G., "Unele reflectii asupra conceptului de incriminare si conceptului de infractiune", en Revista de Drept Penal, No 4, Año XVII, octubre-diciembre, Bucarest, 2010.

__ Vinovăția penalá, Ed., Academiei Romane, Bucarest, 1995.

BALAN, C., Drept Administrativ si Stiinta Administratiei. Suport curs anul II, Universitatea "Alexandru Ioan Cuza”, Iasi, 2009.

BOROI, A., Drept Penal. Partea Specialá, $3^{\mathrm{a}}$ ed., Ed. C.H. Beck, Bucarest, 2016.

BULAI, C., Manual de Drept Penal Partea Generala, Ed. All Educational, Timisoara, 1997.

CILIBIU, O., M., "Consideratii generale privind contraventia", en Analele Univeritatii "Constantin Brancusi" din Targu Jiu, Seria Stiinte Juridice, No 1/2014. 
CIOBANU, A.S., Drept Administrativ II, Sinteze Teórice pentru invatamantul la distanta, Universitatea din $\mathrm{Bu}-$ curesti, Facultatea de Drept, 2012.

DE LA CUESTA AGUADO P. M., Culpabilidad, Exigibilidad y razones para la exculpación, Ed. Dykinson, Madrid, 2003.

DE LA SIERRA, S, Una metodología para el Derecho Comparado europeo, Ed. Thomson Civitas, Madrid, 2004.

DIMA, T., Drept Penal. Partea Generală, $3^{\mathrm{a}}$ ed., Ed. Hamargiu, Bucarest, 2014.

DONGOROZ, V., Drept Penal (Reeditarea editiei din 1939, Ed. Asociatia Ronana de Stiinte Penale, Bucarest, 2000.

DUNGAN, P., "Abuzul în serviciu în noul Cod Penal", en Analele Universitátii de Vest din Timisoara. Seria Drept, núm. 2/2013.

GĂLĂŢEANU, E. O., Teme de Drept Penal General, Ed. Pro Universitaria, Bucarest, 2015.

GORUNESCU, M., "Capitolul II, Infracţiunea și trăsăturile ei esenţiale", en Mirela Gorunescu (coord.), Noul Cod penal pe inţelesul tuturor, Ed. Universul Juridic, Bucarest, 2015.

IVAN, M.C./IVAN, G., Cauzele justificative, Ed. Universul Juridic, Bucarest, 2016.

LEFTERACHE, L. V., Drept Penal. Partea Generală. Curs pentru studenţii anului II, Ed. Hamargiu, Bucarest, 2016.

MINISTERUL PUBLIC. PARCHETUL DE PE LÂNGĂ ÎNALTA CURTE DE CASAȚIE ȘI JUSTIȚIE, "Material Noul Cod Penal”, págs. 15-17. Disponible en: www.mpublic.ro/ro/content7noile-coduri-note-destudiu [consultado el: 27/02/2017].

MITRACHE, C./MITRACHE, C., Drept Penal român. Partea generală, Ed. Universul Juridic, $3^{a}$ ed., Bucarest, 2016.

MUNTEANU, C.D., Administrația publică teritorială, Ed. Universul Juridic, Bucarest, 2010. 
PAȘCA, V., Drept Penal. Partea Generală, $4^{\mathrm{a}}$ ed., Ed. Universul Juridic, Bucarest, 2015.

PASCU, I., "Titlul II. Infracţiunea. Capitolul I. Dispoziţii generale.", en Pascu Ilie (coord.) Noul cod penal comentat, Partea generală, Ed. Universul Juridic, $2^{a}$ ed revăzută si adaugită, Bucarest, 2014.

—Drept Penal Patrea Generală, Ed. Hamargiu, $2^{\mathrm{a}}$ ed., Bucarest, 2009.

PODARU, O./CHIRITA, R./PASCULET, I., Regimul Juridic al contravenţiilor, O.G. nr. 2/2001 comentată, Ed. Hamargiu, $3^{\text {a }}$ d, Bucarest, 2017.

QUINTERO OLIVARES, G., Parte General del Derecho Penal, Ed. Aranzadi, $4^{\mathrm{a}}$ ed., Navarra, 2010.

RICEANU, J. "Analiza trăsăturilor esenţiale ale infracţiunii în legea penală română”, en Revista de Drept Penal, $\mathrm{N}^{\mathrm{o}}$ 1, Anul XVII, ianuarie martie, 2010, Bucarest, págs. $14-27$.

ROTARU, C., "Cauzele justificative și cauzele de neimputabilitate", en Consiliul Superior al Magistraturii. Institutul Național al Magistraturii, Conferințele Noului Cod Penal. Disponible en: http://www.inm-lex.ro/ fisiere/d_176/Rezumatele $\% 20$ conferintelor $\% 20 \mathrm{NCP}$. pdf. [consultado el: 16/02/2017].

ROXIN C., Derecho Penal Parte General, Tomo I, Fundamentos. La estructura de la Teoría del Delito, Ed. Civitas, Madrid, 1997.

STANILĂ, L., "Definiţia infracţiunii în Noul Cod penal şi implicaţiile sale", en Analele Universității de Vest din Timișoara, Núm. 1, 2012, págs. 39-49.

STRETEANU, F., Tratat de drept penal. Partea Generală, Vol I., Ed. C.H. Beck, Bucarest, 2008.

_Drept Penal Partea Generală, Vol. I. Ed. Universul Juridic, Bucarest, 2014

STRETEANU, F./ MOROȘANU, R., Instituţii şi infracţiuni în noul cod penal, Manual pentru uzul formatorilor, ed. SNG, Bucarest, 2010. 
STRETEANU, F/ NIŢU, D., Drept Penal Partea Generală, Vol. I. Ed. Universul Juridic, Bucarest, 2014.

UDROIU, M., Sinteze și Grile. Drept Penal. Parte Generală. Noul Cod Penal, Ed. C.H. Beck, Bucarest, 2014. 